\title{
A PREVALENCE STUDY ON OUTDOOR AIR POLLUTION AND RESPIRATORY DISEASES IN CHILDREN IN ZASAVJE, SLOVENIA, AS A LEVER TO TRIGGER EVIDENCE-BASED ENVIRONMENTAL HEALTH ACTIVITIES
}

\author{
Andreja KUKEC, Jerneja FARKAS, Ivan ERZEN, and Lijana ZALETEL-KRAGELJ \\ Public Health Centre, Faculty of Medicine, University of Ljubljana, Ljubljana, Slovenia \\ Received in October 2011 \\ CrossChecked in December 2011 \\ Accepted in May 2012
}

\begin{abstract}
The aim of this study was to estimate the population burden of respiratory diseases in the Zasavje region of Slovenia that can be attributed to outdoor air pollution in order to gain relevant grounds for evidencebased public health activities. In 2008, 981 schoolchildren (age 6 to 12 years) were observed in a prevalence study. The prevalence of chronic respiratory diseases (CRD) and frequent acute respiratory symptoms (FARS) was related to the level of outdoor air pollution in the local environment (low, moderate and high pollution areas). Logistic regression was used as a method for statistical analysis. The prevalence of CRD was $3.0 \%$ in low pollution areas, $7.5 \%$ in moderate pollution areas, and $9.7 \%$ in high pollution areas ( $p=0.005)$. After adjustment for the effects of confounders, 2.91-times higher odds for CRD were registered in high pollution areas in comparison to low pollution areas $(p=0.017)$. The prevalence of FARS was: $7.8 \%$ in low pollution areas, $13.3 \%$ in moderate pollution areas and $15.9 \%$ in high pollution areas $(p=0.010)$. After adjustment for the effects of confounders, 2.02-times higher odds for FARS were registered in high pollution areas in comparison to low pollution areas $(p=0.023)$. The study confirmed a significantly higher prevalence of CRD and FARS in children living in high pollution areas of Zasavje. These results at least partially prompted mutual understanding and cross-sectoral cooperation - prerequisites for solving complex problems involving the impact of air pollution on health.
\end{abstract}

KEY WORDS: chronic respiratory diseases, frequent acute respiratory symptoms

\section{INTRODUCTION}

Outdoor air pollution is one of the major public health concerns of today. Its adverse effects on human health are numerous (1-4). Children are more susceptible to them than adults due to many reasons. Firstly, more than eighty percent of alveoli are formed postpartum, and changes in the lung continue through adolescence (5-8). Secondly, children have a larger lung surface area per kilogram of body weight than adults and, under normal breathing, they breathe $50 \%$ more air per kilogram of body weight than adults. Finally, children are more exposed to many air pollutants because of higher minute ventilation and, usually, higher levels of physical activity (9-13).

Situated in the central Slovenia, the Zasavje region (or simply Zasavje), (Figure 1) consists of the Zagorje, Trbovlje and Hrastnik municipalities (Figure 2) and is considered to be one of the most polluted regions in the country $(14,15)$. For example, in 2008 the highest 
concentrations of $\mathrm{PM}_{10}$ were measured in urban areas polluted by traffic (Maribor, Ljubljana), industry (Trbovlje, Zagorje ob Savi) and individual heating devices in winter (Zagorje ob Savi). Most exceedances of the daily $\mathrm{PM}_{10}$ limit values were recorded in Zagorje ob Savi (107) and Trbovlje (73). The annual limit value of $\mathrm{PM}_{10}$ was exceeded only in Zagorje ob Savi (16). The Zasavje region encompasses three narrow valleys placed more or less perpendicularly to the larger Sava river valley (Figure 2). Each valley is home to an urban area (small town): Zagorje ob Savi, Trbovlje and Hrastnik (Figure 2). One of the main features of Zasavje are coal mines, which are presently being exhausted and in the closing phase. On the other hand, the Sava river valley has for decades been one of the main Slovenian railway arteries. Consequently, many different centres of heavy industry were placed in Zasavje, among others one of the biggest steam power plants in Slovenia. The power plant, as well as cement, glass, chemical, and other industries, are mainly situated at the junction of the Zagorje, Trbovlje and Hrastnik valleys with the Sava valley (Figure 2). Ever since its establishment, the local industry has had an enormous impact on the environment. The most important pollution in the past was caused by sulphur dioxide $\left(\mathrm{SO}_{2}\right)$ and particulate matter (PM). However, according to the latest report of the Environmental Agency of the Republic of Slovenia (EARS), $\mathrm{SO}_{2}$ levels have greatly improved, and the national legally-defined maximum values are exceeded only exceptionally (in the period 2000-2010, the average annual concentration of $\mathrm{SO}_{2}$ reduced from $22 \mu \mathrm{g} \mathrm{m}^{-3}$ to $\left.6 \mu \mathrm{g} \mathrm{m}^{-3}\right)$. Measurements of $\mathrm{PM}_{10}$ and ozone levels at monitoring stations in Zasavje show that they constantly exceed the national legallydefined maximum values $\left(\mathrm{PM}_{10}\right.$ : in the period 2000 2010 , the average annual concentration decreased from $46 \mu \mathrm{g} \mathrm{m}^{-3}$ to $36 \mu \mathrm{g} \mathrm{m}^{-3}$; ozone: in the period 2000-2010, the average annual concentration increased from $41 \mu \mathrm{g} \mathrm{m}^{-3}$ to $\left.44 \mu \mathrm{g} \mathrm{m}^{-3}\right)(15,17,18)$.

Due to the geographical and meteorological characteristics of the region, the impact of pollutants is even stronger. Wind direction and speed in the Zasavje mountainous terrain vary considerably. The predominant wind directions are north and southsouth-east, while south-west, north and east winds are much less represented. The average wind speed in all directions is very low - very rarely do winds blow at speeds above $10 \mathrm{~m} \mathrm{~s}^{-1}(19,20)$. Temperature inversions are frequently present in winter and autumn in the lower points of the valleys. Both animals and plants frequently suffer the consequences. Recent

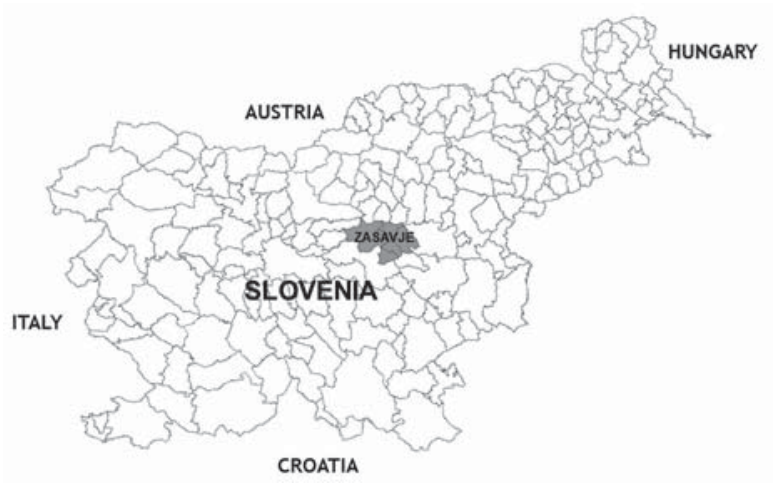

Figure 1 The location of Zasavje region in Slovenia

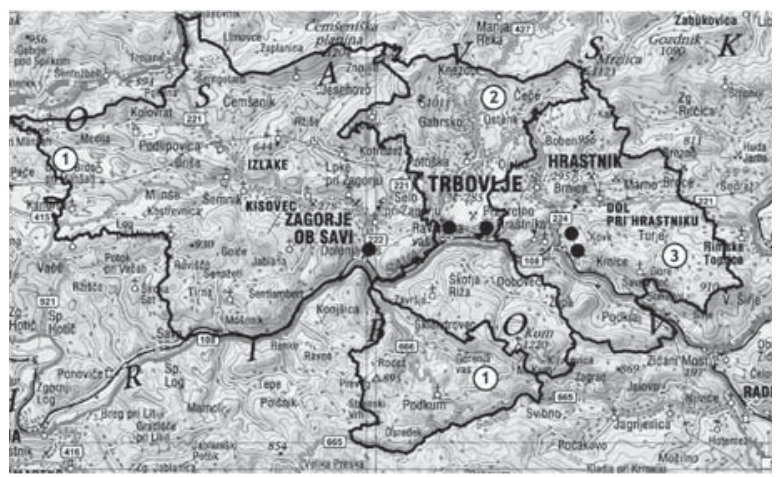

Figure 2 Zasavje region map with locations of main point sources of outdoor air pollution in the region. LEGEND: $1=$ Zagorje municipality; 2 = Trbovlje municipality; $3=$ Hrastnik municipality; $\bullet$ = location of lime and plaster plant, cement plant, steam power plant, chemical plant and glass plant; $\mathbf{-}=$ houses/settlements (font size of the settlement name indicate the rough size of the settlement)

environmental studies have shown extensive pollution of plants with $\mathrm{SO}_{2}$ and fluorides, lichen with cadmium and lead, roe deer with cadmium and mercury, and air with $\mathrm{PM}_{10}(21,22)$. Unfortunately, few studies have studied the relationship between environmental pollution and health among the Zasavje population $(23,24)$. New impetus to performing research was given in 2005, when activities began for acquiring environmental licenses for co-combustion of certain types of solid waste in the local cement plant. More precisely, the population of Zagorje municipality became concerned and an environmental impact study on selected diseases and mortality was carried out for the municipality population. It indicated an association between the level of environmental pollution and the prevalence of chronic respiratory diseases (25). However, further study needed to consider several potential confounders in order to yield a clear and purposeful relationship between environmental pollution and respiratory diseases in children of all three Zasavje municipalities. This would enable making future 
evidence-based decisions regarding environmental health.

The aim of this study was to evaluate if the prevalence of respiratory diseases among schoolchildren in the Zasavje municipalities was associated with the level of outdoor air pollution in residing areas. Our hypothesis was that the prevalence of respiratory diseases in schoolchildren residing in those Zasavje areas which were estimated to be more polluted was higher than in schoolchildren residing in less polluted areas. The study was also initiated with the intention to trigger stronger cross-sectoral cooperation necessary to solve complex problems of air pollution impact on health in Zasavje.

\section{PARTICIPANTS AND METHODS}

\section{Participants}

The data was collected in February and March of 2008 in a cross-sectional study. The entire population of Zasavje schoolchildren from the first to fifth grade of primary school (approximately 6 to 11 years of age, in total 1790 schoolchildren) was invited to participate in the study: 769 from Zagorje (total population: 17,167), 624 from Trbovlje (total population: 17,761), and 397 from the Hrastnik municipality (total population: 10,298).

At the beginning of the study, parents/guardians were asked to fill in a questionnaire about their child's past health issues, especially if they involved acute and chronic respiratory diseases, as well as several conditions that could influence respiratory diseases: outdoor and indoor air conditions, smoking habits, living conditions, socioeconomic conditions and others. The parents/guardians of the children were informed about the purpose and methodology of the study and asked to sign an informed consent. The study protocol was approved by the Ethical Committee of the Republic of Slovenia in February, 2008.

The questionnaires were distributed to the schoolchildren by their class teachers. In order to assure the highest level of anonymity, parents/ guardians were asked to return the filled-in questionnaires by mail in an enclosed envelope marked "Confidential, do not open" to the Ljubljana Regional Institute of Public Health.

\section{Observed outcomes}

The observed outcomes included two types of respiratory disease. The first was a chronic respiratory disease (CRD) diagnosed by a physician (personal paediatrician or paediatrician-specialist for respiratory diseases). In order to accomplish this estimate, parents/ guardians were asked to answer the following question: "Has a medical doctor ever told you that your child has (or that there is suspicion of) asthma or other chronic respiratory disease (like chronic bronchitis, mucoviscidosis, bronchiectasiae, etc.)?". The second type was the presence of frequent acute respiratory symptoms (FARS) in the last year, as assessed by parents/guardians. In order to obtain this estimate, parents/guardians were asked to answer the following question: "During your child's health problems, did they include frequent respiratory diseases (wheeze, runny nose, etc.) of short duration?". These two outcomes were related to the level of outdoor air pollution in the residence environment.

\section{Assessment of outdoor air pollution levels}

In order to verify our hypothesis, we defined an estimate of the level of outdoor air pollution in the residence environment of the schoolchildren. Due to problems with environmental measurements in Zasavje, the estimate was obtained with the aid of the local Zasavje population. In fact, we combined two estimates. Both estimates were obtained independently from one another. The first was the estimate of parents/ guardians, who were asked to assess the outdoor air pollution on a 5-level ordinal scale (1-no pollution, 2very low pollution, 3-moderate pollution, 4-high pollution, and 5-very high pollution). The second was the estimate of the local nongovernmental organization Eko Krog Society (EKS), which has been striving to accomplish a cleaner environment in the Zasavje region for nearly a decade. In order to obtain this estimate, representatives of the EKS were asked to provide estimates for the same locations as parents/guardians and on the same 5-level ordinal scale. However, EKS representatives decided to provide their estimates on a 9-level ordinal scale, ranging from 1-no pollution to 9 -very high pollution. Ultimately, these two estimates were merged into a single final estimate on a 3-level ordinal scale, which provided the following estimate of the outdoor air pollution level: 1-low, 2-moderate, 3high. The process of integration entailed three steps. During this process, the estimate of the parents/guardians was determined as more important and thus became a baseline estimate. In the first step, the parents/guardians estimate was translated to a 9-level scale $(1=1,2=3,3=5$, $4=7,5=9$ ). In the second step, both estimates were compared. When the estimates were congruent, the 9- 
level scale was translated to a 3 -level scale ( 1 to $3=1,4$ to $6=2,7$ to $9=3$ ). When the estimates were not congruent, the procedure was as follows: when the EKS estimate had differed no more than two levels from the parents/ guardians estimate on a 9-level scale, the parents/ guardians estimate was interpreted by the final 3-level classification; otherwise the EKS estimate was taken into consideration, since these estimates were occasionally accompanied by unofficial environmental measurements. For example, if the parents/guardians classified their microenvironment as belonging to category 4 ( 7 when translated to a 9-level scale), and EKS classified the same area as category 6 or 5 (originally on a 9-level scale), the estimate was classified according to the parents/guardians' opinion (and finally in category 3 on a 3-level scale). If the EKS would estimate the level of pollution as being category 4 (originally on a 9-level scale), the same estimate would be classified according to the opinion of the EKS (and finally in category 2 on a 3-level scale).

\section{Statistical analysis}

Overall differences and differences within strata of selected potential confounders (accompanying risk factors) were analysed using the chi-square test. The following accompanying risk factors were considered potential confounders: sex (male, female); heredity of a respiratory disease: (no, yes); age (8 years or less, 9 years ormore); problems during pregnancy (e.g. hyperirritability of uterus) (no, yes); regular physical activity during pregnancy (no, yes); smoking during pregnancy (no, yes); stress perception of mother during pregnancy (no, yes); complications just after the delivery (no, yes); breast-feeding duration (less than 8 months vs. 8 months or more); exposure to passive smoking in early childhood (no, yes); exposure to passive smoking in present time (no, yes); very high or high humidity of dwelling place in spring, autumn and/or winter (no, yes); exposure to animal allergens in early childhood (no, yes); exposure to animal allergens in present time (no, yes); social class (lowest or labour vs. middle or higher); family structure (living with both parents vs. other), and number of people living in the same household (2 to 3, 4, 5 or more).

Differences in the prevalence of acute/chronic respiratory diseases between areas of different environmental pollution levels were later adjusted to the effects of potential confounders using multiple logistic regression (26). When dummy variables were created, the group for which, according to previous knowledge, the lowest prevalence was expected was assigned as the reference group. For both chronic and acute respiratory diseases, two models were defined. In Model 1, only the estimated level of outdoor air pollution in the residence area was considered. In Model 2 , all potential confounders considered in the study were included along with the estimated level of outdoor air pollution in the residence area as the explanatory variable.

In all statistical tests, $p$-value 0.05 or less was considered significant. The SPSS statistical package for Windows Version 18.0 (SPSS Inc., Chicago, IL, USA) was used for analysis.

\section{RESULTS}

Response to the survey and description of the study group

The overall response rate was $65.5 \%$ (1172 of 1790$)$, but it varied substantially among the municipalities. At $71.8 \%$ (552 of 769), the rate was highest in the Zagorje municipality, while the lowest rate was recorded in the Hrastnik municipality at $49.1 \%$ (195 of 397). In the Trbovlje municipality, the rate was $68.1 \%$ (425 of 624).

In order to avoid potential bias due to a low response rate, we excluded 187 respondents from the Hrastnik municipality from the analysis. We also excluded four respondents residing in one of the neighbouring municipalities. The final study group comprised 981 schoolchildren who were permanent residents of the Zagorje (554) or Trbovlje (427) municipalities at the time of the study. Some details on the study group are presented in Table 1.

\section{Chronic respiratory diseases}

The presence/absence of CRD was established in 974 of $981(99.3 \%)$ respondents. Among them 67 (6.9\%) had CRD.

When relating the prevalence of CRD to the outdoor air pollution level of the children's residence area, establishing both the presence/absence of CRD and an estimate of the air pollution level was possible for 946 schoolchildren. The results of this analysis showed a clear gradient. In low pollution areas, the prevalence of CRD was $3.0 \%$ (8 of 268), in moderate pollution areas it was $7.5 \%$ (23 of 307), while in high pollution areas the rate was $9.7 \%$ (36 of 371). The difference was statistically significant $(p=0.005)$. Prevalence of CRD in different population groups according to categories of potential risk factors is presented in Table 2. The 
Table 1 Description of schoolchildren residing in Zasavje, Slovenia, that responded to the survey on impact of outdoor air pollution on respiratory diseases burden in Zasavje, 2008

\begin{tabular}{lccc}
\hline Characteristic & & $\boldsymbol{N}_{\text {tot }}$ & $\boldsymbol{N}_{\text {cat }}(\%)$ \\
\hline Sex & Boys & 975 & $476(48.8)$ \\
& Girls & & $499(51.2)$ \\
\hline Grade & $1^{\text {st }}(6$ to 7 years old $)$ & 980 & $168(17.1)$ \\
& $2^{\text {nd }}(7$ to 8 years old $)$ & & $171(17.4)$ \\
& $3^{\text {rd }}(8$ to 9 years old $)$ & & $216(22.0)$ \\
& $4^{\text {th }}(9$ to 10 years old $)$ & & $209(21.3)$ \\
& $5^{\text {th }}(10$ to 11 years old $)$ & & $216(22.0)$ \\
\hline Estimated level of outdoor air & Low & 951 & $268(28.2)$ \\
pollution of permanent & Moderate & & $308(32.4)$ \\
residence area & High & & $375(39.4)$ \\
\hline
\end{tabular}

Legend: $\mathrm{N}_{\text {tot }}=$ total number of respondents; $\mathrm{N}_{\text {cat }}=$ number of respondents within the category.

prevalence of CRD was significantly higher in schoolchildren with a family history of respiratory disease, health complications just after delivery, and a breast-feeding period less than 8 months (Table 2).

In order to relate CRD with the estimated outdoor air pollution level in a multivariate analysis adjusted for confounders, we collected all the necessary data for 780 participants. The results of the logistic regression analysis showed that, in the basic model, the children from moderate pollution areas had 2.27-times higher odds of having a CRD than children from low pollution areas $(p=0.042$ ), while children from high pollution areas had 2.85-times higher odds of having a CRD than children from low pollution level area $(p=0.006)$. After adjustment for effects of all potential confounders considered in the study, only the difference between high pollution areas and low pollution areas remained statistically significant (Table 3 ).

\section{Frequent acute respiratory symptoms}

The presence/absence of FARS could be established in 976 of $981(99.5 \%)$ respondents. Among them 123 $(12.6 \%)$ schoolchildren had FARS.

When relating the prevalence of FARS to the outdoor air pollution level of the children's residence, establishing both the presence/absence of FARS and the estimated level of air pollution was possible for 948 schoolchildren. The results of this analysis also showed a clear gradient. In low pollution areas, the prevalence of FARS was $7.8 \%$ (21 of 268), in moderate pollution areas it was $13.3 \%$ (41 of 308), while in high pollution areas the rate was $15.9 \%$ ( 59 of 372 ). The difference was statistically significant $(p=0.010)$. The prevalence of FARS in different population groups according to categories of potential risk factors is presented in Table 4. The prevalence of FARS was significantly higher in schoolchildren with health complications just after the delivery, whose mothers had pregnancy complications and who lived in a dwelling place with high or very high humidity (Table 4).

In order to relate FARS with the estimated outdoor air pollution level in a multivariate analysis adjusted for confounders, we collected all the necessary data for 782 participants. The results of logistic regression analysis showed that, in the basic model, the children from moderate pollution areas had 1.66-times higher odds of having a FARS than children from low pollution areas $(p=0.076)$, while children from high outdoor air pollution areas had 2.18-times higher odds of having a FARS than children from low pollution areas $(p=0.004)$. After adjustment for effects of all potential confounders considered in the study only the difference between high pollution areas and low pollution areas remained statistically significant (Table 5).

\section{DISCUSSION}

The results of our study indicated that the burden of respiratory diseases, both acute and chronic, was significantly higher in children residing in high pollution areas in comparison to those residing in low pollution areas of Zasavje. Also, the burden was higher, though not statistically significant, in children residing in moderate pollution areas in comparison to children residing in low pollution areas. These results are in line with the results of other similar studies, which showed that children living in highly polluted areas display a higher prevalence of respiratory symptoms and impaired lung function than those living in moderately and less- 
Table 2 Estimates of prevalence (per 100 of population) of chronic respiratory diseases (CRD) according to different potential risk factors in schoolchildren residing in Zasavje, Slovenia, that responded to the survey on impact of outdoor air pollution on respiratory diseases burden in Zasavje, 2008

\begin{tabular}{|c|c|c|c|c|c|}
\hline Risk factor & & $N_{\text {tot }}$ & $N_{\text {CRD }} / N_{\text {cat }}$ & $(\%)$ & $p$ \\
\hline \multirow[t]{2}{*}{ Sex } & Girls & 968 & $28 / 498$ & 5.6 & 0.101 \\
\hline & Boys & & $39 / 470$ & 8.3 & \\
\hline \multirow[t]{2}{*}{ Age } & 8 years or less & 972 & $24 / 326$ & 7.4 & 0.682 \\
\hline & 9 years or more & & $43 / 646$ & 6.7 & \\
\hline Family history of chronic & No & 955 & $39 / 718$ & 5.4 & 0.006 \\
\hline respiratory disease & Yes & & $25 / 237$ & 10.5 & \\
\hline \multirow[t]{2}{*}{ Pregnancy complications } & No & 968 & $39 / 660$ & 5.9 & 0.100 \\
\hline & Yes & & $27 / 308$ & 8.8 & \\
\hline \multirow[t]{2}{*}{ Smoking of mother during pregnancy } & No & 966 & $54 / 817$ & 6.6 & 0.521 \\
\hline & Yes & & $12 / 149$ & 8.1 & \\
\hline Distress of mother during & No & 960 & $53 / 785$ & 6.8 & 0.823 \\
\hline pregnancy & Yes & & $11 / 175$ & 6.3 & \\
\hline Child's health complication just & No & 963 & $56 / 883$ & 6.3 & 0.037 \\
\hline after the delivery & Yes & & $10 / 80$ & 12.5 & \\
\hline \multirow[t]{2}{*}{ Breast-feeding duration } & Less than 8 months & 966 & $51 / 572$ & 8.9 & 0.004 \\
\hline & 8 months or more & & $16 / 394$ & 4.1 & \\
\hline Exposure to passive smoking in early & No & 961 & $44 / 666$ & 6.6 & 0.771 \\
\hline childhood & Yes & & $21 / 295$ & 7.1 & \\
\hline Exposure to passive smoking in & No & 955 & $47 / 733$ & 6.4 & 0.269 \\
\hline present time & Yes & & $19 / 222$ & 8.6 & \\
\hline Very high or high humidity of & No & 924 & $56 / 830$ & 6.7 & 0.310 \\
\hline dwelling place & Yes & & $9 / 94$ & 9.6 & \\
\hline Exposure to animal allergens in early & No & 956 & $50 / 685$ & 7.3 & 0.160 \\
\hline childhood & Yes & & $13 / 271$ & 4.8 & \\
\hline Exposure to animal allergens in & No & 964 & $52 / 712$ & 7.3 & 0.469 \\
\hline present time & Yes & & $15 / 252$ & 6.0 & \\
\hline \multirow[t]{2}{*}{ Social class } & Lowest or labour & 889 & $20 / 271$ & 7.4 & 0.686 \\
\hline & Middle or higher & & $41 / 618$ & 6.6 & \\
\hline \multirow[t]{2}{*}{ Family structure } & Living with both parents & 971 & $56 / 844$ & 6.6 & 0.401 \\
\hline & Other & & $11 / 127$ & 8.7 & \\
\hline Number of people living in & 2 to 3 & 972 & $13 / 212$ & 6.1 & 0.876 \\
\hline \multirow[t]{2}{*}{ same household } & 4 & & $38 / 541$ & 7.0 & \\
\hline & 5 or more & & $16 / 219$ & 7.3 & \\
\hline
\end{tabular}

Legend: $\mathrm{N}_{\text {tot }}=$ total number of respondents; $\mathrm{N}_{C R D}=$ number of children with CRD within the category; $\mathrm{N}_{\text {cat }}=$ number of respondents within the category.

polluted areas $(27,28)$. We can also compare these results to the results of the study performed in the Zagorje municipality in 2005 (25). It showed that schoolchildren from the more polluted areas of the Zagorje municipality had 3.5-times higher odds for chronic bronchitis than children from less polluted areas. Similar results were observed in asthma and allergy, where the odds were 1.3-times and 1.6-times higher, respectively.

It is important to point out that the association between observed outcomes and the estimated level of outdoor air pollution in the permanent residence area as an explanatory variable only slightly changed after adjustment for possible important confounders. This indicates that the estimated coefficients are relatively stable. Examining the results on confounders, some factors seem to have played an important role in the population. One such factor with CRD is a family history of CRD. This is consistent with the findings of Ronchetti et al. (29) and De Marco et al. (30). They have both found that a family history of asthma or allergy is associated with a higher risk of developing asthma in children. The second factor (a protective one) is breastfeeding. This is consistent with the findings of Kull et al. (31), who found that exclusive breast-feeding for 4 
Table 3 Results of logistic regression analysis of impact of level of outdoor air pollution on chronic respiratory diseases in 780 schoolchildren residing in Zasavje, Slovenia, that responded to the survey on impact of outdoor air pollution on respiratory diseases burden in Zasavje, 2008

\begin{tabular}{|c|c|c|c|c|c|}
\hline \multirow[t]{2}{*}{ Explanatory/confounding factor } & & \multirow[t]{2}{*}{ OR } & \multicolumn{2}{|c|}{$\begin{array}{c}95 \% \text { C.I. limits for } \\
\text { OR }\end{array}$} & \multirow[t]{2}{*}{$p$} \\
\hline & & & lower & upper & \\
\hline Estimated level of outdoor air & Low & 1.00 & & & \\
\hline pollution of permanent & Moderate & 2.27 & 0.93 & 5.54 & 0.071 \\
\hline residence area & High & 2.91 & 1.21 & 7.00 & 0.017 \\
\hline \multirow[t]{2}{*}{ Sex } & Girls & 1.00 & & & \\
\hline & Boys & 1.55 & 0.87 & 2.76 & 0.141 \\
\hline \multirow[t]{2}{*}{ Age } & 8 years or less & 1.00 & & & \\
\hline & 9 years or more & 0.95 & 0.51 & 1.76 & 0.872 \\
\hline Family history of chronic & No & 1.00 & & & \\
\hline respiratory disease & Yes & 2.27 & 1.25 & 4.13 & 0.007 \\
\hline \multirow[t]{2}{*}{ Pregnancy complications } & No & 1.00 & & & \\
\hline & Yes & 1.46 & 0.81 & 2.65 & 0.211 \\
\hline Smoking of mother during & No & 1.00 & & & \\
\hline pregnancy & Yes & 1.31 & 0.59 & 2.88 & 0.507 \\
\hline Distress of mother during & No & 1.00 & & & \\
\hline pregnancy & Yes & 0.85 & 0.39 & 1.85 & 0.689 \\
\hline Child's health complication just & No & 1.00 & & & \\
\hline after the delivery & Yes & 0.91 & 0.35 & 2.38 & 0.855 \\
\hline \multirow[t]{2}{*}{ Breast-feeding duration } & 8 months or more & 1.00 & & & \\
\hline & Less than 8 months & 2.59 & 1.32 & 5.07 & 0.006 \\
\hline Exposure to passive smoking in & No & 1.00 & & & \\
\hline early childhood & Yes & 0.95 & 0.43 & 2.09 & 0.896 \\
\hline Exposure to passive smoking in & No & 1.00 & & & \\
\hline present time & Yes & 0.89 & 0.36 & 2.19 & 0.840 \\
\hline Very high or high humidity of & No & 1.00 & & & \\
\hline dwelling place & Yes & 1.20 & 0.47 & 3.04 & 0.700 \\
\hline Exposure to animal allergens in & No & 1.00 & & & \\
\hline early childhood & Yes & 0.61 & 0.29 & 1.29 & 0.200 \\
\hline Exposure to animal allergens in & No & 1.00 & & & \\
\hline present time & Yes & 0.84 & 0.41 & 1.75 & 0.645 \\
\hline \multirow[t]{2}{*}{ Social class } & Middle or higher & 1.00 & & & \\
\hline & Lowest or labour & 1.25 & 0.66 & 2.38 & 0.487 \\
\hline \multirow[t]{2}{*}{ Family structure } & Living with both parents & 1.00 & & & \\
\hline & Other & 1.54 & 0.64 & 3.72 & 0.333 \\
\hline Number of people living in & 2 to 3 & 1.00 & & & \\
\hline \multirow[t]{2}{*}{ same household } & 4 & 1.60 & 0.72 & 3.58 & 0.252 \\
\hline & 5 or more & 1.52 & 0.60 & 3.79 & 0.377 \\
\hline
\end{tabular}

Abbreviations: OR - odds ratio; C.I. - confidence interval

months or more reduced the risk of asthma at the age of 4 years. With FARS, the child's health complications immediately after birth is the primary factor, which is to a certain extent consistent with the findings of Holditch-Davis et al. (32), who reported that postneonatal health problems in combination with one's social environment appear to be important factors in developing wheezing in prematurely born children. The second factor is the humidity of the residence. In our study, children living in high or very humid dwelling places demonstrate a higher prevalence of FARS. This is consistent with the findings of Platt et al. (33), who reported that children living in damp and mouldy dwellings had a higher prevalence of respiratory symptoms (wheeze, sore throat, runny nose), headaches and fever compared with those living in dry dwellings. 
Table 4 Estimates of prevalence (per 100 of population) of frequent acute respiratory symptoms (FARS) according to different potential risk factors in schoolchildren residing in Zasavje, Slovenia, that responded to the survey on impact of outdoor air pollution on respiratory diseases burden in Zasavje, 2008

\begin{tabular}{|c|c|c|c|c|c|}
\hline Risk factor & & $N_{\text {tot }}$ & $N_{\text {FARS }} / N_{\text {cat }}$ & $(\%)$ & $p$ \\
\hline \multirow[t]{2}{*}{ Sex } & Girls & 970 & $58 / 497$ & 11.7 & 0.382 \\
\hline & Boys & & $64 / 473$ & 13.5 & \\
\hline \multirow[t]{2}{*}{ Age } & 8 years or less & 974 & $43 / 326$ & 13.2 & 0.708 \\
\hline & 9 years or more & & $80 / 648$ & 12.3 & \\
\hline Family history of chronic & No & 957 & $81 / 720$ & 11.3 & 0.053 \\
\hline respiratory disease & Yes & & $38 / 237$ & 16.0 & \\
\hline \multirow[t]{2}{*}{ Pregnancy complications } & No & 970 & $73 / 662$ & 11.0 & 0.023 \\
\hline & Yes & & $50 / 308$ & 16.2 & \\
\hline \multirow{2}{*}{ Smoking of mother during pregnancy } & No & 970 & $100 / 821$ & 12.2 & 0.272 \\
\hline & Yes & & $23 / 149$ & 15.4 & \\
\hline Distress of mother during & No & 964 & 99/788 & 12.6 & 0.982 \\
\hline pregnancy & Yes & & $22 / 176$ & 12.5 & \\
\hline Child's health complication just & No & 965 & $101 / 884$ & 11.4 & $<0.001$ \\
\hline after the delivery & Yes & & $22 / 81$ & 27.2 & \\
\hline \multirow{2}{*}{ Breast-feeding duration } & Less than 8 months & 968 & $76 / 574$ & 13.2 & 0.400 \\
\hline & 8 months or more & & $45 / 394$ & 11.4 & \\
\hline Exposure to passive smoking in early & No & 962 & $82 / 667$ & 12.3 & 0.689 \\
\hline childhood & Yes & & $39 / 295$ & 13.2 & \\
\hline Exposure to passive smoking in present & No & 957 & $91 / 736$ & 12.4 & 0.516 \\
\hline time & Yes & & $31 / 221$ & 14.0 & \\
\hline High or very high humidity of dwelling & No & 928 & $98 / 833$ & 11.8 & 0.002 \\
\hline place & Yes & & $22 / 95$ & 23.2 & \\
\hline Exposure to animal allergens in early & No & 957 & $86 / 686$ & 12.5 & 0.755 \\
\hline childhood & Yes & & $36 / 271$ & 13.3 & \\
\hline Exposure to animal allergens in present & No & 966 & $91 / 715$ & 12.7 & 0.993 \\
\hline time & Yes & & $32 / 251$ & 12.7 & \\
\hline \multirow[t]{2}{*}{ Social class } & Lowest or labour & 892 & $35 / 273$ & 12.8 & 0.966 \\
\hline & Middle or higher & & $80 / 619$ & 12.9 & \\
\hline \multirow[t]{2}{*}{ Family structure } & Living with both parents & 973 & $105 / 844$ & 12.4 & 0.630 \\
\hline & Other & & $18 / 129$ & 14.0 & \\
\hline Number of people living in & 2 to 3 & 974 & $20 / 212$ & 9.4 & 0.199 \\
\hline \multirow[t]{2}{*}{ same household } & 4 & & $70 / 544$ & 12.9 & \\
\hline & 5 or more & & $33 / 218$ & 15.1 & \\
\hline
\end{tabular}

The results of the study by Tavernier et al. (34) were similar. The third factor is the number of people living in the same household. In our study, children living in bigger families indicated a higher prevalence of FARS. This is consistent with the findings of Alves Cardoso et al. (35), who reported that crowding was associated with a decreased incidence of asthma diagnoses but an increased incidence of lower respiratory tract infections in children. It is important to note that some of these factors can and should be mitigated. However, we could not find sufficient evidence for a relationship between respiratory diseases in children and variables of sex and age, pregnancy complications, smoking during pregnancy, distress during pregnancy, exposure to passive smoking in early childhood or in present time, exposure to animal allergens early or presently, social class, and family structure.

The present study has some limitations. Firstly, despite the fact that Zasavje is one of the most polluted Slovenian regions, routine air quality data is measured only at three national air quality monitoring stations, located in the centres of the urban areas Zagorje ob Savi, Trbovlje and Hrastnik (15). Apart from that, this routinely collected data possesses several limitations: a) questionable spatial representativeness of the monitoring sites, b) certain pollutants are not measured 
Table 5 Results of logistic regression analysis of impact of level of outdoor air pollution on frequent acute respiratory symptoms in 782 schoolchildren residing in Zasavje, Slovenia, that responded to the survey on impact of outdoor air pollution on respiratory diseases burden in Zasavje, 2008

\begin{tabular}{|c|c|c|c|c|c|}
\hline \multirow[t]{2}{*}{ Explanatory/confounding factor } & & \multirow[t]{2}{*}{ OR } & \multicolumn{2}{|c|}{$\begin{array}{c}95 \% \text { C.I. limits for } \\
\text { OR }\end{array}$} & \multirow[t]{2}{*}{$p$} \\
\hline & & & lower & upper & \\
\hline Estimated level of outdoor air & Low & 1.00 & & & \\
\hline pollution of permanent & Moderate & 1.68 & 0.89 & 3.14 & 0.107 \\
\hline residence area & High & 2.02 & 1.10 & 3.69 & 0.023 \\
\hline \multirow[t]{2}{*}{ Sex } & Girls & 1.00 & & & \\
\hline & Boys & 1.15 & 0.74 & 1.78 & 0.528 \\
\hline \multirow[t]{2}{*}{ Age } & 8 years or less & 1.00 & & & \\
\hline & 9 years or more & 0.93 & 0.59 & 1.46 & 0.746 \\
\hline Family history of chronic & No & 1.00 & & & \\
\hline respiratory disease & Yes & 1.49 & 0.93 & 2.39 & 0.097 \\
\hline \multirow[t]{2}{*}{ Pregnancy complications } & No & 1.00 & & & \\
\hline & Yes & 1.27 & 0.80 & 2.01 & 0.306 \\
\hline Smoking of mother during & No & 1.00 & & & \\
\hline pregnancy & Yes & 1.24 & 0.67 & 2.29 & 0.485 \\
\hline Distress of mother during & No & 1.00 & & & \\
\hline pregnancy & Yes & 0.90 & 0.52 & 1.57 & 0.719 \\
\hline Child's health complication just & No & 1.00 & & & \\
\hline after the delivery & Yes & 2.16 & 1.13 & 4.12 & 0.019 \\
\hline \multirow[t]{2}{*}{ Breast-feeding duration } & 8 months or more & 1.00 & & & \\
\hline & Less than 8 months & 1.32 & 0.83 & 2.09 & 0.240 \\
\hline Exposure to passive smoking in & No & 1.00 & & & \\
\hline early childhood & Yes & 0.96 & 0.53 & 1.76 & 0.902 \\
\hline Exposure to passive smoking in & No & 1.00 & & & \\
\hline present time & Yes & 1.23 & 0.64 & 2.38 & 0.537 \\
\hline High or very high humidity of & No & 1.00 & & & \\
\hline dwelling place & Yes & 2.85 & 1.55 & 5.23 & 0.001 \\
\hline Exposure to animal allergens in & No & 1.00 & & & \\
\hline early childhood & Yes & 1.05 & 0.62 & 1.76 & 0.857 \\
\hline Exposure to animal allergens in & No & 1.00 & & & \\
\hline present time & Yes & 0.75 & 0.44 & 1.30 & 0.313 \\
\hline \multirow[t]{2}{*}{ Social class } & Middle or higher & 1.00 & & & \\
\hline & Lowest or labour & 0.74 & 0.45 & 1.23 & 0.250 \\
\hline \multirow[t]{2}{*}{ Family structure } & Living with both parents & 1.00 & & & \\
\hline & Other & 1.46 & 0.74 & 2.89 & 0.270 \\
\hline Number of people living in & 2 to 3 & 1.00 & & & \\
\hline \multirow[t]{2}{*}{ same household } & 4 & 1.74 & 0.91 & 3.33 & 0.096 \\
\hline & 5 or more & 2.53 & 1.24 & 5.14 & 0.010 \\
\hline
\end{tabular}

Abbreviations: OR - odds ratio; C.I. - confidence interval

$\left(\mathrm{PM}_{10}\right.$ in Hrastnik and $\mathrm{NO}_{2}$ in Zagorje were not measured at the time of the study), and c) frequent errors in measurements. Also, residents constantly dispute the representativeness of the data. There are also supplementary data which are collected using mobile devices on five locations around the steam power plant (15). However, they are not publicly available. That is why we decided to use the parents' estimates and combine them with the estimate of the EKS. These two estimates possess certain drawbacks, as well. Specifically, the parents' estimate could be substantially biased. For example, one could argue against the notion that parents can determine the severity of air pollution without being trained to do 
so. However, major pollutants in the Zasavje region display obvious signs: the degree of PM pollution can be roughly estimated by observing the thickness of dust deposits on, for instance, window sills. $\mathrm{SO}_{2}$ is a colourless gas with a specific odour that causes irritation, while ozone is a colourless gas with a pungent smell. Nevertheless, there exists a possibility that the parents' observations coincide with previous air pollutant determinations and/or with the location of the main sources of pollution. Due to this possible bias, the parents' estimate was combined with the estimate of the EKS, which is partially based on measurements. However, a combination of these two estimates also possesses advantages - parents assess micro-circumstances that could hardly be assessed without placing several measurement devices throughout the entire Zasavje region. One could also argue against the fact that the estimate of parents/guardians was determined to be more important than the EKS estimate. Given the design of the study, which fundamentally provides all information obtained through questions directed at parents/guardians, we decided that this estimate will also be obtained in the same manner. The EKS estimate was used only as a means to mitigate the potential bias present in the parents/guardians estimate. Secondly, one could argue against the use of the crosssectional study design. Misclassification of cases and controls is a potential concern in this type of studies. In a cross-sectional study, the causal inference is based on a comparison of the prevalence of asthma and chronic bronchitis in subjects currently exposed and not exposed. A major weakness of this approach is the uncertainty in temporality, an important criterion of causality (36). However, similar study designs have already been used in studying environmental health problems (37). Moreover, our intention was not to rediscover the facts that have already been discussed in many other studies, but to draw attention to a specific problem and trigger an adequately strong response. For this reason, a crosssectional study design that is among the cheapest study designs was chosen as optimal. Thirdly, the children were classified as diseased or not diseased according to the answers from the questionnaire and no special medical examination was undertaken in order to verify their diagnoses. However, it could be asserted that the degree of misclassification is not substantial because the questionnaires were filled out by parents/guardians, who are usually very well-acquainted with the health status of their children, especially regarding chronic diseases. Fourthly, it is possible that several parents whose children were not ill did not fill out the questionnaire
(38), meaning that the global prevalence in Zasavje may not be as high as was observed, but due to the method of collecting the data, unfortunately we could not assess which Zasavje area had the lowest number of submitted questionnaires. On the other hand, the overall response rate in our study was much higher than in the Community Action Against Asthma (CAAA) project, Michigan, U.S. (about $35 \%$ ) (39). Fifthly, in this study we also measured a chronic health effect that started a while ago and was linked to certain environmental conditions that existed a few years ago. This means that the present situation regarding the environmental situation could be considerably different from the situation prevailing a few years back and that the conclusions derived from present data could be false. Furthermore, one could argue against the claim that the prevalence of CRD and FARS found in our study is not a substantial problem if compared to the extent of its presence in other countries (40). However, despite the fact that the concentrations of some pollutants (especially $\mathrm{SO}_{2}$ ) decreased in Zasavje after filter devices were installed in certain industrial plants and district heating was set up in all three urban areas resulting in the decreased usage of domestic coal with high sulphur content (17), the problem of pollution with $\mathrm{PM}_{10}$ still persists. Finally, one could argue against the exclusion of 187 respondents from the Hrastnik municipality from the analysis. Our decision to exclude them was based on the fact that the response rate in this municipality was rather low. Although there is no agreedupon standard for the minimum acceptable response rate, there is general consensus that at least half of the sample needs to complete the survey instrument. Some authors are even more rigorous and discard response rates below $60 \%$, or even $75 \%$, as unacceptable (41). Since the response rate in the Hrastnik municipality was below $50 \%$, we assessed the likelihood of the response bias/nonresponse error in the Hrastnik group of respondents as being too large to be considered representative of the total population. It could be that the study attracted a number of people from the Hrastnik municipality who were more motivated to participate in the survey than others, e.g. they perceived their living environment as heavily polluted or they had children with health conditions. We ultimately excluded this group from the analysis.

However, the present study also has several strengths. Firstly, the study offers valuable initial information about the burden of respiratory diseases in Zasavje schoolchildren associated with air pollution in the region. This information could be used as valuable for planning public health interventions, especially in situations in 
which a timely reaction is required (e.g. in the prevention of new/additional pollution by building new/additional industrial objects). This study can also be used as a model in environments where it is difficult or impossible to get measurement data instantly or at all, since this type of study requires minimal financial resources. We believe that many transitional countries face similar problems and that this approach could also prove useful in those countries, as well. Finally, the study provides important information (e.g. on potential confounders) that could be used in further research in the field, for example in population-level studies (multiple-group ecological studies). This type of studies is strongly needed since new sources of pollution constantly appear. As we pointed out in the introduction, the problem of outdoor air pollution in Zasavje is emphasized by the mountainous terrain and meteorological conditions which are highlighted even more when one considers the reactions of primary pollutants that generate new pollutants in the atmosphere in the presence of sun energy. Often these pollutants can hardly (or not at all) be seen or scented. They can be even more harmful to human health than primary pollutants. One such pollutant are polychlorinated dibenzodioxins. In Zasavje, most sources of this group of pollutants are already present, which poses a potentially great burden for the Zasavje population. The exposure of children to these pollutants is a particular concern.

Based on the results of the study, a framework for environmental health interventions at the individual/ intrapersonal, interpersonal, organizational, community, and society/policy level $(39,42)$, as well as targets for change (e.g. resources, policies, community capacity, social networks and behaviour) (42) could be set. In fact, some necessary steps have already been taken. This study represented an exposure assessment component for a larger project, entitled "From detailed environmental and health analysis to reducing health inequalities in Zasavje". This component was accompanied by an intervention component. Among several specific objectives of the intervention component, some were focused on environmental health at the intrapersonal (identification and management of health risk factors from the environment) and interpersonal level (improvement of links between the various groups and organizations within a community - networking). Thus, three levels of intervention still remain to be tackled. However, planning interventions at these levels needs additional and much stronger evidence. Fortunately, the study has at least partially prompted mutual understanding and cross-sectoral cooperation, which is strongly required in solving complex problems of the impact of air pollution on human health. The first success was that health (represented by the Ljubljana University Faculty of Medicine and Faculty of Health Sciences) and environmental professions (represented by the EARS) jointly applied for funding in order to implement a research project in the frame of the target (applied) research programme "Competitiveness of Slovenia 2006-2013" on the topic of "Support of the design and implementation of sectoral and intersectoral policies in the field of environment and health (specific target air pollution health impact assessment) ". The tender was launched by the Ministry of Higher Education, Science and Technology of the Republic of Slovenia. The project is aimed to obtain evidence of air pollution health impact at the population level by using the methodology proposed by the World Health Organization $(43,44)$, including air quality modelling.

In conclusion, the first goal of our study was fully achieved, considering that the results confirmed a significantly higher prevalence of respiratory diseases in schoolchildren living in high and moderate pollution level areas of Zasavje. The second goal was also achieved. However, the coordinated actions of all sectors still require a lot of work.

\section{Acknowledgements}

This study was conducted as part of a larger project entitled "From detailed environmental and health analysis to reducing health inequalities in Zasavje", which was financially supported by the Ministry of health of the Republic of Slovenia. The authors thank Rudi Zupan, MD, Natalija Vidergar, BSc, PhD, Magdalena Lusic, MD, MSc, and Marko Vudrag, MD, $\mathrm{PhD}$, Project Co-ordinator, for their contribution to this study. We are also deeply grateful to parents/ guardians, schoolchildren and teachers who participated in our study.

\section{REFERENCES}

1. World Health Organization(WHO). Quantification of the Health Effects of Exposure to Air Pollution. Report on a WHO Working Group, Bilthoven, Netherlands, 20-22 November 2000. Copenhagen: WHO Regional Publications; 2001.

2. Zanobetti A, Schwartz J, Samoli E, Gryparis A, Touloumi G, Peacock J, Anderson RH, Le Tertre A, Bobros J, Celko M, Goren A, Forsberg B, Michelozzi P, Rabczenko D, Hoyos SP, Wichmann HE, Katsouyanni K. The temporal pattern of 
respiratory and heart disease mortality in response to air pollution. Environ Health Perspect 2003;111:1188-93.

3. Makri A, Stilianakis NI. Vulnerability to air pollution health effects. Int J Hyg Environ Health 2008;211:326-36.

4. Lindgren A, Stroh E, Montnémery P, Nihlén U, Jakobsson $\mathrm{K}$, Axmon A. Traffic-related air pollution associated with prevalence of asthma and COPD/chronic bronchitis. A crosssectional study in Southern Sweden. Int J Health Geogr 2009;8:2. doi:10.1186/1476-072X-8-2

5. Burri PH. Structural aspects of prenatal and postnatal development and growth of the lung. In: McDonald JA, editor. Lung growth and development. New York (NY): Marcel Dekker; 1997. p. 1-35.

6. Schwartz J. Air pollution and children's health. Pediatrics 2004;113:1037-43.

7. Etzel RA. Indoor and outdoor air pollution: Tobacco smoke, moulds and diseases in infants and children. Int J Hyg Environ Health 2007;210:611-6.

8. Suwanwaiphatthana W, Ruangdej K, Turner-Henson A. Outdoor air pollution and children's health. Pediatr Nurs 2010;36:25-32.

9. Tamburlini G, Ehrenstein OS, Bertolini R, editors. Children's Health and Environment: A Review of Evidence. Luxembourg: Office for Official Publications of the European Communities; 2002.

10. American Academy of Pediatrics. Ambient air pollution: health hazards to children. Pediatrics 2004;114:1699-707.

11. World Health Organization (WHO). Effects of Air Pollution on Children's Health and Development. A Review of the Evidence. Copenhagen: WHO, Regional Office for Europe; 2005.

12. Buka I, Koranteng S, Osornio-Vargas AR. The effects of air pollution on the health of children. Paediatr Child Health 2006; 11:513-6.

13. Kasamatsu J, Shima M, Yamazaki S, Tamura K, Sun G. Effects of winter air pollution on pulmonary function of school children in Shenyang, China. Int J Hyg Environ Health 2006;209:435-44.

14. ERICo Inštitut za ekološke raziskave. Onesnaženost okolja in naravni viri kot dejavnik razvoja v zasavski regiji modelni pristop. Zaključno poročilo. [Environmental pollution and natural resources as factors of development in Zasavje region - a model approach. Final report, in Slovene]. Velenje: ERICo; 2001.

15. Bolte T, Segula A, Fasing J, Rode B, Lesnjak M, Gartner D, Gjerek M, Lesnik M, Turk D. Ocena onesnaženosti zraka z $\mathrm{SO}_{2}, \mathrm{NO}_{2}, \mathrm{PM}_{10}$, svincem, $\mathrm{CO}$, benzenom, težkimi kovinami in policikličnimi aromatskimi ogljikovodiki v Sloveniji. [Assessment of air pollution by $\mathrm{SO}_{2}, \mathrm{NO}_{2}, \mathrm{PM}_{10}$, lead, $\mathrm{CO}$, benzene, heavy metals and polycyclic aromatic hydrocarbons in Slovenia, in Slovene]. Ljubljana: EARS Publications; 2009.

16. Agencija Republike Slovenie za okolje. Onesnaženost zraka z delci $\mathrm{PM}_{10}$ in $\mathrm{PM}_{2.5}$ [Outdoor air pollution by $\mathrm{PM}_{10}$ and $\mathrm{PM}_{2.5}$, in Slovene] [displayed 15 February 2012]. Available at http:// kazalci.arso.gov.si/?data=indicator\&ind_id $=232$

17. Agencija Republike Slovenie za okolje. Poročilo o kakovosti zraka za leto 2006. Zaključno poročilo. [Air quality in Slovenia in the year 2006. Final Report, in Slovene]. Ljubljana: EARS; 2007.

18. Agencija Republike Slovenie za okolje. Kakovost zraka poročila in publikacije [Outdoor air quality - annual reports, in
Slovene] [displayed 15 February 2012]. Available at http:// www.arso.gov.si/zrak/kakovost \%20zraka/poro\%c4\%8dila $\% 20$ in\%20publikacije/

19. Agencija Republike Slovenie za okolje. Značilnosti podnebja v občini Zagorje ob Savi. Zaključno poročilo. [Climate characteristics in the Zagorje municipality. Final Report, in Slovene]. Ljubljana: EARS; 2006.

20. Agencija Republike Slovenie za okolje. Značilnosti podnebja v občinah Trbovlje in Hrastnik. Zaključno poročilo. [Climate characteristics in the Trbovlje and Hrastnik municipality. Final Report, in Slovene]. Ljubljana: EARS; 2008.

21. Plut D. Geografske zasnove sonaravnega načrtovanja regionalnega napredka Zasavske regije. [Geographical plans on sustainable planning region development in Zasavje region, in Slovene]. Dela 2002;18:505-16.

22. Energy Institute. Delež velikih nepremičnih virov emisij pri obremenjevanju zraka v Zasavju ter njihov vpliv na kakovost zraka v Zasavju. Zaključno poročilo. [Part of large point sources of emission and their influence on air quality in Zasavje region. Final Report, in Slovene]. Ljubljana: Energy Institute; 2007.

23. Lusic M. Alergijske bolezni dihal pri otrokih v Zasavju. V: Otrokom zdravo in varno okolje. Zbornik prispevkov. [Allergic respiratory disease in children in Zasavje. In: Slovenian Association of Friends of Youth. Healthy and safe environment for children, collection of contributions, in Slovene]. Ljubljana: Slovenian Association of Friends of Youth; 1990.

24. Lusic M. Vpliv stopnje onesnaženosti zraka na pogostost hospitalizacije zaradi bolezni dihal na Otroškem oddelku v Trbovljah. V: Onesnaženo okolje in otrok. Izvlečki razprav. [The impact of the level of air pollution on the frequency of hospital admissions due to respiratory diseases at the Paediatric Ward of Trbovlje Hospital. In: Slovenian Medical Association, Pediatric Section. Polluted environment and a child. Abstract of discussions, in Slovene]. Trbovlje, Ljubljana: Slovenian Medical Association, Pediatric Section; 1995.

25. Erzen I, Vertacnik G, Podkrajsek D, Juricic M, Ursic A, Zadnik V, Zaletel-Kragelj L. Proučevanje vpliva okolja na pojav določenih bolezni in povečano stopnjo umrljivosti prebivalcev na območju občine Zagorje ob Savi. Zaključno poročilo. [A study on environmental impact on selected diseases and mortality of population of Zagorje municipality. Final report, in Slovene]. Celje: Regional Institute of Public Health Celje; 2006.

26. Hosmer DW, Lemeshow S. Applied Logistic Regression. $2^{\text {nd }}$ ed. New York (NY): John Wiley \& Sons; 2000.

27. Langkulsen U, Jinsart W, Karita K, Yano E. Respiratory symptoms and lung function in Bangkok school children. Eur J Public Health 2006;16:676-81.

28. Nordling E, Berglind N, Melen E, Emenius G, Hallberg J, Nyberg F, Pershagen G, Svartengren M, Wickman M, Bellander T. Traffic-related air pollution and childhood respiratory symptoms, function and allergies. Epidemiology 2008;19:401-8.

29. Ronchetti R, Villa MP, Barreto M, Rota R, Pagani J, Martella S, Falasca C, Paggi B, Guglielmi F, Ciofetta G. Is the increase in childhood asthma coming to an end? Findings from three surveys of schoolchildren in Rome, Italy. Eur Respir J 2001;17:881-6. 
30. De Marco R, Pattaro C, Locatelli F, Svanes C; ECRHS Study Group. Influence of early life exposures on incidence and remission of asthma throughout life. J Allergy Clin Immunol 2004;113:845-52.

31. Kull I, Almquist C, Lilja G, Pershagen G, Wickman M. Breast-feeding reduces the risk of asthma during the first 4 years of life. J Allergy Clin Immunol 2004;114:755-60.

32. Holditch-Davis D, Merrill P, Schwartz T, Scher M. Predictors of wheezing in prematurely born children. J Obstet Gynecol Neonatal Nurs 2008;37:262-73.

33. Platt SD, Martin CJ, Hunt SM, Lewis CW. Damp housing, mould growth, and symptomatic health state. Br Med J 1989;298:1673-8.

34. Tavernier G, Fletcher G, Gee I, Watson A, Blacklock G, Francis H, Fletcher A, Frank T, Frank P, Pickering CA, Niven R. IPEADAM study: Indoor endotoxin exposure, family status, and some housing characteristics in English children. J Allergy Clin Immunol 2006;117:656-62.

35. Alves Cardoso MR, Cousens SN, De Goes Siqueira LF, Alves FM, D'Angelo LA. Crowding: risk factor or protective factor for lower respiratory disease in young children? BMC Public Health 2004;4:19. doi:10.1186/1471-2458-4-19

36. Eggleston PA, Buckley TJ, Breysee PN, Wills-Karp M, Kleeberger SR, Jaakkola JK. The environment and asthma in U.S. inner cities. Environ Health Perspect 1999;107(Suppl 3):439-50

37. Karadžinska-Bislimovska J, Minov J, Stoleski S, Mijakoski D, Risteska-Kuc S, Milkovska S. Environmental and occupational health risks among agricultural workers living in a rural community near petroleum refinery and motorway in Skopje region. Arh Hig Rada Toksikol 2010;61:415-24.

38. World Health Organization (WHO). Health Research Methodology. A Guide for Training in Research Methods. $2^{\text {nd }}$ ed. Manila: WHO Regional Office for the Western Pacific; 2001.

39. Parker EA, Grant TB, Israel B, Salinas MA. Application of health promotion theories and models for environmental health. Health Educ Behav 2004;31:491-509.

40. Wirl C, Puklova V. Prevalence of asthma and allergies in children (ENHIS 2007 fact sheet 3.1). Copenhagen: WHO Regional Office for Europe; 2007.

41. Draugalis JR, Coons SJ, Plaza CM. Best practices for survey research reports: a synopsis for authors and reviewers. Am J Pharm Educ 2008;72:1-6.

42. Crozier-Kegler M, Miner K. Environmental health promotion interventions: considerations for preparation and practice. Health Educ Behav 2004;31:510-25.

43. Briggs $\mathrm{D}$, Corvalán $\mathrm{C}$, Nurminen $\mathrm{M}$, editors. Linkage Methods for Environment and Health Analysis. General Guidelines. Geneva: WHO Office of Global and Integrated Environmental Health; 1996.

44. Corvalán $\mathrm{C}$, Nurminen M, Pastides H, editors. Linkage Methods for Environment and Health Analysis. Technical Guidelines. Geneva: WHO Office of Global and Integrated Environmental Health; 1997. 


\section{Izvleček}

ŠTUDIJA POVEZANOSTI MED PREVALENCO BOLEZNI DIHAL PRI OTROCIH IN ONESNAŽENOSTJO ZUNANJEGA ZRAKA V ZASAVJU KOT VZVOD ZA SPROŽITEV Z DOKAZI PODPRTIH AKTIVNOSTI ZA IZBOLJŠANJE OKOLJSKEGA ZDRAVJA

Namen raziskave je bilo oceniti breme bolezni dihal v Zasavju v Sloveniji, ki ga je mogoče pripisati onesnaženosti zunanjega zraka, da bi dobili ustrezno podlago za z dokazi podprte javnozdravstvene aktivnosti. Podatke smo zbrali v presečni raziskavi v začetku leta 2008 pri 981 otrocih, starih 6 do 12 let. Opazovali smo povezanost med prevalenco kroničnih bolezni dihal (KBD) in pogostih akutnih respiratornih simptomov (PARS) ter stopnjo onesnaženosti zunanjega zraka na območju stalnega prebivališča otrok (nizko, srednje in visoko onesnaženo območje). Podatke smo analizirali z metodo logistične regresije. Prevalenca KBD je bila: 3,0 \% na območju z nizko, 7,5 \% na območju s srednjo in 9,7 \% na območju z visoko stopnjo onesnaženosti $(p=0,005)$. Po upoštevanju motečih dejavnikov je bilo razmerje obetov med nizko in visoko onesnaženima območjema $2,91 \mathrm{v}$ korist slednjega $(p=0,017)$. Prevalenca PARS je bila: $7,8 \%$ na območju z nizko, $13,3 \%$ na območju s srednjo in $15,9 \%$ na območju $\mathrm{z}$ visoko stopnjo onesnaženosti $(p=0,010)$. Po upoštevanju motečih dejavnikov je bilo razmerje obetov med nizko in visoko onesnaženima območjema 2,02 v korist slednjega $(p=0,023)$. Rezultati raziskave so tako potrdili značilno višjo prevalenco KBD in PARS pri otrocih, ki živijo na območjih Zasavja, ki so ocenjena kot visoko onesnažena. Ti rezultati so vsaj deloma sprožili medsektorsko razumevanje in sodelovanje, ki je zelo potrebno pri reševanju kompleksnih problemov vplivov onesnaženega zraka na zdravje.

KLJUČNE BESEDE: kronične bolezni dihal, onesnaženost zraka, otroci, pogosti akutni respiratorni simptomi

\section{CORRESPONDING AUTHOR:}

Lijana Zaletel-Kragelj

Faculty of Medicine, Chair of Public Health

Zaloska 4

1000 Ljubljana, Slovenia

E-mail: lijana.kragelj@mf.uni-lj.si 